\title{
Waning antibody responses in COVID-19: what can we learn from the analysis of other coronaviruses?
}

\author{
Ali Hamady ${ }^{1}$ (D) . JinJu Lee ${ }^{1}$ (D) $\cdot$ Zuzanna A. Loboda $^{1}$ (D)
}

Received: 11 March 2021 / Accepted: 8 July 2021 / Published online: 29 July 2021

(c) The Author(s) 2021

\begin{abstract}
Objectives The coronavirus disease 2019 (COVID-19), caused by the novel betacoronavirus severe acute respiratory syndrome 2 (SARS-CoV-2), was declared a pandemic in March 2020. Due to the continuing surge in incidence and mortality globally, determining whether protective, long-term immunity develops after initial infection or vaccination has become critical.

Methods/Results In this narrative review, we evaluate the latest understanding of antibody-mediated immunity to SARS$\mathrm{CoV}-2$ and to other coronaviruses (SARS-CoV, Middle East respiratory syndrome coronavirus and the four endemic human coronaviruses) in order to predict the consequences of antibody waning on long-term immunity against SARS-CoV-2. We summarise their antibody dynamics, including the potential effects of cross-reactivity and antibody waning on vaccination and other public health strategies. At present, based on our comparison with other coronaviruses we estimate that natural antibody-mediated protection for SARS-CoV-2 is likely to last for 1-2 years and therefore, if vaccine-induced antibodies follow a similar course, booster doses may be required. However, other factors such as memory B- and T-cells and new viral strains will also affect the duration of both natural and vaccine-mediated immunity.

Conclusion Overall, antibody titres required for protection are yet to be established and inaccuracies of serological methods may be affecting this. We expect that with standardisation of serological testing and studies with longer follow-up, the implications of antibody waning will become clearer.
\end{abstract}

Keywords COVID-19 $\cdot$ SARS $\cdot$ MERS $\cdot \mathrm{HCoV} \cdot$ Antibodies

\begin{tabular}{|c|c|}
\hline \multicolumn{2}{|c|}{ Abbreviations } \\
\hline COVID-19 & Coronavirus disease 2019 \\
\hline SARS-CoV-2 & $\begin{array}{l}\text { Severe acute respiratory syndrome corona- } \\
\text { virus } 2\end{array}$ \\
\hline SARS-CoV & $\begin{array}{l}\text { Severe acute respiratory syndrome } \\
\text { coronavirus }\end{array}$ \\
\hline MERS-CoV & $\begin{array}{l}\text { Middle East respiratory syndrome } \\
\text { coronavirus }\end{array}$ \\
\hline $\mathrm{HCoVs}$ & $\begin{array}{l}\text { Human coronaviruses (HCoV- } \\
\text { 229E, HCoV-OC43, HCoV-NL63, } \\
\text { HCoV-HKU1) }\end{array}$ \\
\hline $\mathrm{nAb}$ & Neutralising antibody \\
\hline RBD & Receptor-binding domain \\
\hline $\mathrm{MBC}$ & Memory B-cell \\
\hline MTC & Memory T-cell \\
\hline
\end{tabular}

Zuzanna A. Loboda

zal17@ic.ac.uk

1 Department of Immunology and Inflammation, Imperial College London, London, UK
ART
BCG
Antiretroviral therapy
CPTT
Bacillus Calmette-Guérin
ADE
Convalescent plasma transfer therapy
ELISA
Antibody-dependent enhancement
PRNT
Enzyme-linked immunosorbent assay
Plaque reduction neutralisation test

\section{Introduction}

Severe acute respiratory syndrome coronavirus 2 (SARSCoV-2) was declared a pandemic in March 2020 by the World Health Organization. As of June 2021, it has caused over 3.8 million deaths and almost 180 million confirmed infections [1]. After intensive efforts from the scientific community over the past year, vaccines are now available. Almost all routine vaccinations rely on antibody responses [2], especially neutralising antibodies (nAbs), which are thought to be the best correlate of protection [3]. These can reduce infectivity by preventing attachment of the virion to 
the target cell, thereby blocking viral entry and therefore, replication [3].

Progression of some phase I/II trials of COVID-19 vaccines has depended solely on the magnitude of antibody response elicited, e.g. the immunogenicity endpoint of the BNT162b1 vaccine included $\mathrm{nAb}$ and receptor-binding domain (RBD)-binding IgG antibody titres [4] with no reports of B- or T-cell levels. However, recent studies have reported the rapid waning of antibodies following SARSCoV-2 infection [5-7]. There is limited knowledge about the implications of this on long-term immunity, which is pertinent to address to ensure the success of public health strategies.

Seven coronaviruses are known to infect humans to date. Four of these are human coronaviruses (HCoVs) 229E, NL63, OC43 and HKU1, which cause relatively mild symptoms and circulate as endemic strains of the common cold. The other three, Middle East respiratory syndrome coronavirus (MERS-CoV), SARS-CoV and SARS-CoV-2 can cause life-threatening respiratory infections [8]. However, even the HCoVs may have started as more severe infections, e.g. OC43 has been stated as a possible aetiological agent for the "Russian flu" pandemic [9]. Their clinical and non-clinical characteristics have been summarised below (Table 1).

Coronaviruses are composed of four structural proteins including spike, envelope, membrane and nucleocapsid [13]. Cellular infection occurs when the RBD of the spike protein's $\mathrm{S} 1$ subunit attaches to its host cellular receptor, causing a conformational change in the $\mathrm{S} 2$ subunit which mediates fusion and entry into the cell [26]. Antibodies to this spike protein have been shown to be most important in providing protective immunity in SARS-CoV [27]. Given the genetic homology and similarity in spike proteins between MERS-CoV, SARS-CoV and SARS-CoV-2, antibody responses to these viruses may demonstrate a certain degree of similarity and parallels may be drawn between their pathogenicity $[12,13]$.

This narrative review aims to compare the antibody responses to different human coronaviruses to further our understanding of long-term immunity in SARS-CoV-2. We critically summarise the evidence for the duration and efficacy of antibodies in protective immunity and explore the implications of antibody waning on public health strategies. We also discuss some links between antibody waning, crossreactivity and vaccine efficacy which may be important in future research.

\section{Methods}

After deciding the title and subtitles, we conducted searches on the PubMed and Embase databases up to June 20, 2021. Ahead-of-print publications and those on preprint servers were included given the fast developments in the COVID19 pandemic. The search included keywords such as: "antibod*", "seropositiv*", "cross-reacti*" and "immun*" alongside "COVID-19" (OR "SARS-CoV-2"), "HCoV_*" (OR "seasonal coronavirus"), "MERS*" or "SARS-CoV" (OR "SARS"). Most articles retrieved were primary research papers. We also identified articles from the reference lists of other papers. We did not contact authors to obtain unpublished data. Figures of antibody kinetics are solely a graphical representation of the estimated trend in $\mathrm{nAb}$ titres based on severity and waning over time, generated using various studies.

\section{Antibody waning in coronavirus infections}

\section{SARS-CoV}

IgM antibodies reach peak titres $\sim 1$ month postsymptom onset [28-30]. whereas $\mathrm{IgG}$ and $\mathrm{nAb}$ reach theirs $\sim 2-4$ months [28-32] and 1-4 months [29, 31], respectively. Subsequent titres of IgM begin a relatively rapid decline, decreasing steadily to undetectable levels $\sim 6$ months post-symptom onset [29, 32]. IgG and $\mathrm{nAb}$ display a more gradual and closely correlated pattern in their waning, approaching values for seronegativity $\sim 2$ years postsymptom onset (Fig. 1a) [28, 29, 31]. At $\sim 3$ years, close to half of initially $\mathrm{IgG}$ positive patients revert to seronegative status [29] and by 6 years, almost all patients revert to IgG seronegativity to SARS-CoV [33].

Higher titres of $\mathrm{nAb}$ are positively correlated with symptomatic and more severe clinical disease [34-36] but whether the severity of disease affects subsequent antibody waning is not clear, with conflicting results found in different studies $[31,34,37]$. The presence of underlying comorbidities, age and steroid use does not appear to be associated with different antibody kinetics [31,37], though it has been noted that men exhibit a more pronounced decrease in $\mathrm{nAb}$ titres compared to women [31,34].

\section{MERS-CoV}

Robust antibody responses to MERS-CoV develop by week 3 [38-41]. IgG titres decline during weeks 4-5 and though the IgM titres start decreasing earlier, they are seropositive for $>1$ month, albeit at a lower titre than IgG [39]. Observations have been made that while a more severe disease is associated with higher antibody titre peaks [38, 42-44], a delayed nAb response has been observed [40, 42]. Although antibody waning occurs, IgG and nAbs are detectable $>1$ year post-symptom onset [41, 43-45], with cases of antibody persistence for up to 34 months in recovered individuals [45]. Importantly, antibodies wane at a slower 


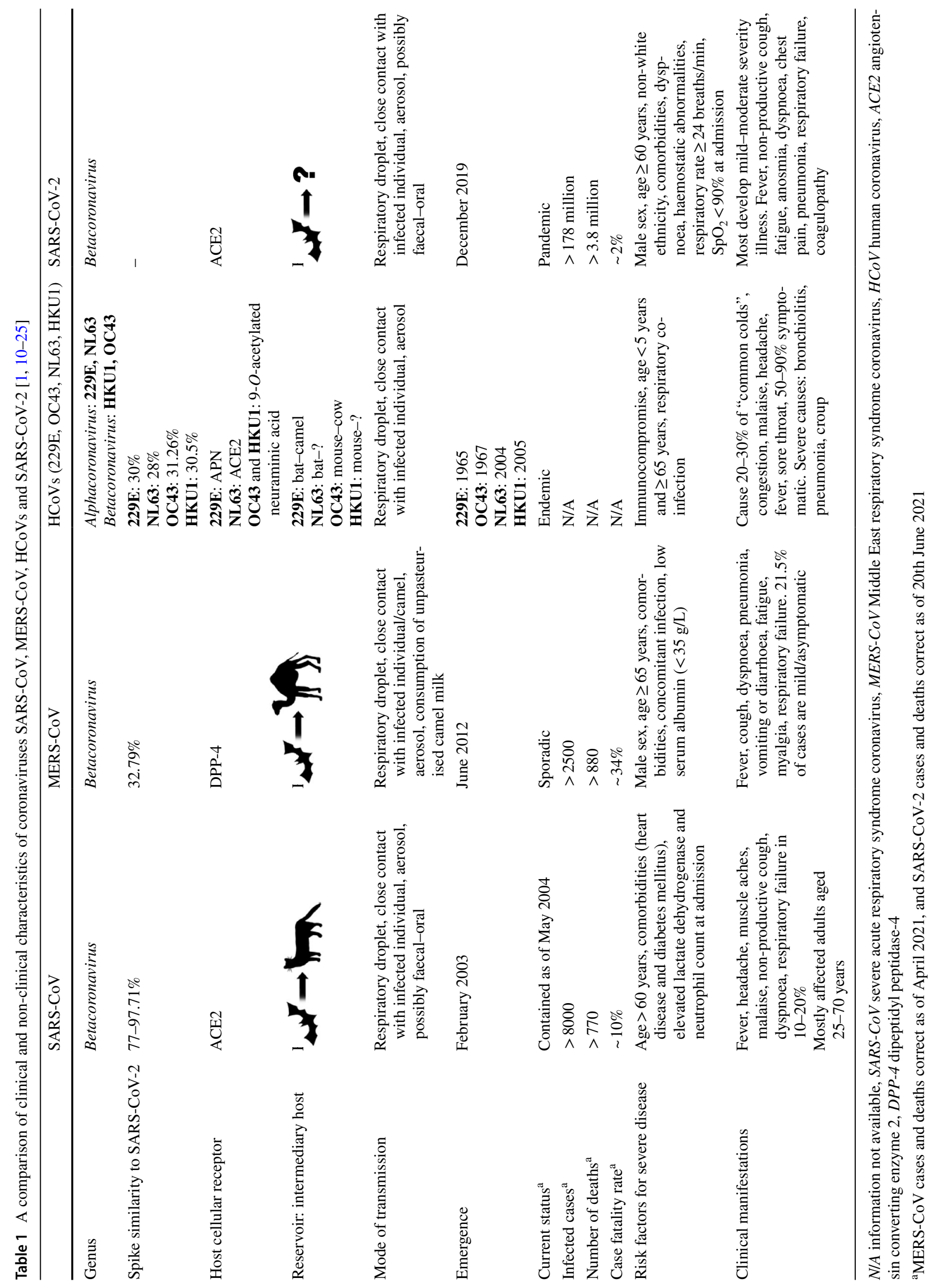


Fig. 1 Graphical representation of the longevity and magnitude of the $\mathrm{nAb}$ antibody response to coronaviruses. a Shows trends in antibody kinetics to SARSCoV, MERS-CoV and HCoVs, highlighting the relatively rapid waning of $\mathrm{HCoV}$ nAbs as well as higher titres generated in severe SARS-CoV/MERS-CoV infection [28-32, 34-38, 40-42, $44,52]$. The dotted line indicates a lack of serological data for common cold coronavirus infections in individuals naïve to the infection. b Compares antibody titre trends in severe and mild SARS-CoV-2 and their waning over time, highlighting the higher titres generated in severe infection [56-58, 60, 62-64]. Neither graph drawn to scale. SARS-CoV severe acute respiratory syndrome coronavirus, $M E R S$ - $C o V$ Middle East respiratory syndrome coronavirus, $H C o V$ human coronavirus
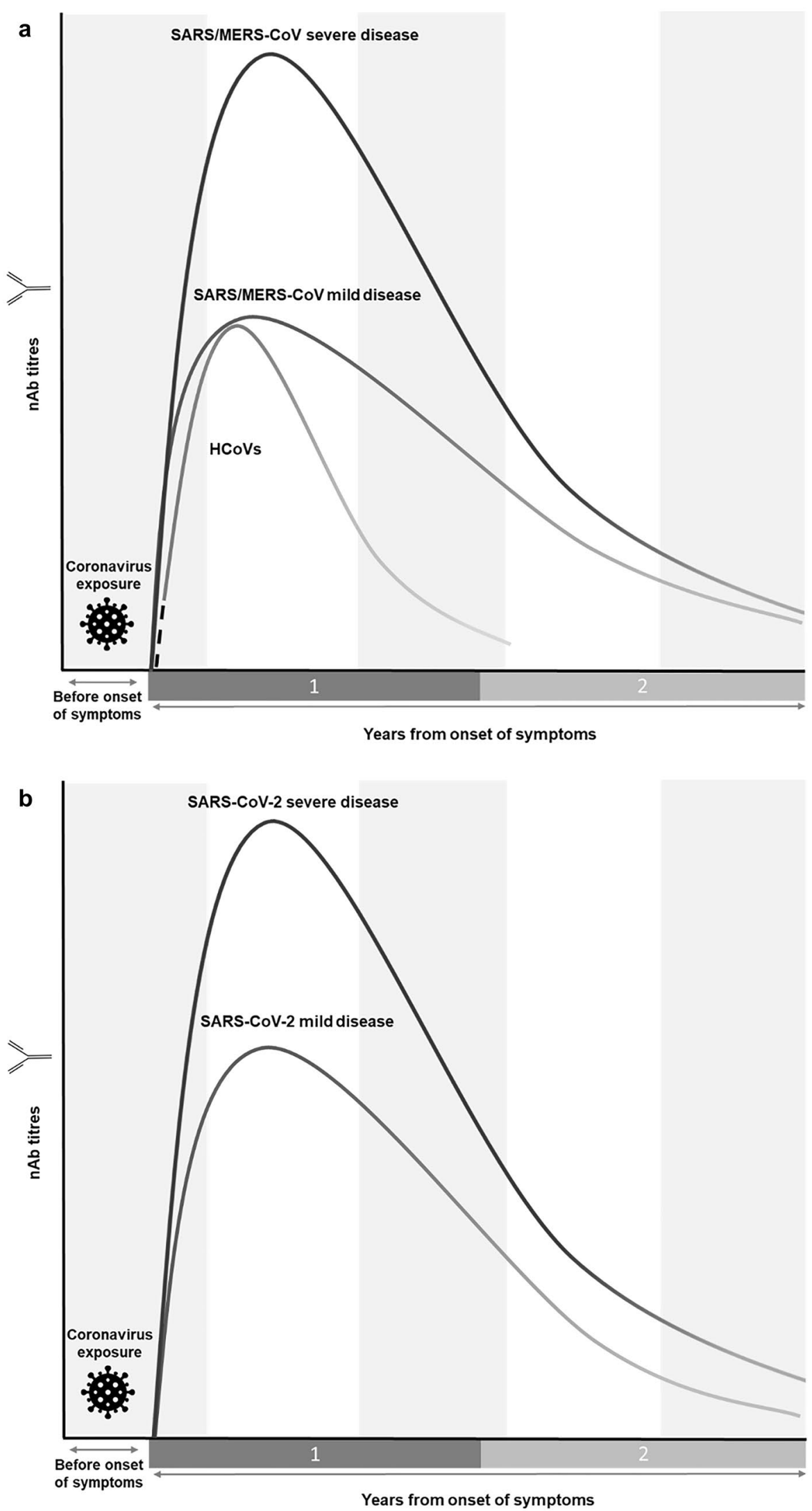
rate during months $6-12$ compared to the first 6 months post-symptom onset (Fig. 1a) [44]. Additionally, antibody response longevity correlates with disease severity [43, 44] such that most patients with severe disease have detectable IgG and $\mathrm{nAb}$ after 1 year compared to $33 \%$ of individuals who experienced mild disease [44]. On the other hand, age does not seem to be correlated with nAb response [46], however, few studies have investigated this factor.

\section{HCoVs}

Antibodies to $\mathrm{HCoV}$ infections may be protective but wane quickly. Seroepidemiological studies have shown $\mathrm{HCoV}$ IgM to be present in children but absent in adults, indicating that first infection occurs during childhood [47]. The majority of seroconversion is reported to occur before the age of 3.5 years [48]. Persistence of antibodies in the adult population is likely related to frequent reinfection [49-51]. Experimental infection with $\mathrm{HCoV}-229 \mathrm{E}$ has shown that peaks of total IgM, IgG and nAb titres occur 12-14 days after inoculation, falling considerably by 12 weeks and to near baseline levels by 52 weeks (Fig. 1a) [52]. However, unlike serological studies of SARS-CoV, SARS-CoV-2 and MERS-CoV, where patients are most likely naïve to the infection, population seropositivity to $\mathrm{HCoVs}$ is high which affects the conclusions which can be drawn from human challenge studies [53]. In one study, antibodies to the four HCoVs were detectable in $>70 \%$ of the adult population [48]. Reinfections after challenge may not be due to a lack of immunity but rather due to the unusually high inoculum dose [54].

\section{SARS-CoV-2}

In a SARS-CoV-2 study, three different patterns of seroconversion have been observed. In some, IgM appears before $\mathrm{IgG}$ as expected, in others they occur simultaneously and sometimes IgM appears after IgG [5]. Overall, IgM, IgG and $\mathrm{nAb}$ titres peak $\sim 2-3$ weeks post-symptom onset and decline to undetectable levels by 6 weeks for $\operatorname{IgM}$, whereas $\operatorname{IgG}$ and $\mathrm{nAb}$ reach a plateau before declining within 2-3 months (Fig. 1b) [6, 55-57]. Mathematical modelling estimates that within 1 year IgG antibodies to nucleocapsid, spike protein and RBD wane to $7 \%, 36 \%$ and $31 \%$ of their titres at 2 weeks post-symptom onset, respectively [58]. Additionally, nAb responses seem to correlate with disease severity [7, 56, 59], with antibody half-lives of 31 and 69 days in asymptomatic and severe infections, respectively [60].

IgG titres to SARS-CoV-2 infection are negatively correlated with age for those $<18$ years but positively correlated with age in adults [61]. Within 6 months post-symptom onset, older adults (44-66-year-olds) seem to maintain higher IgG levels than younger adults (18- to 44-year-olds) but no difference is observed at 12 months post-symptom onset [62]. In children, the narrower breadth of anti-SARSCoV-2-specific antibodies, specifically with reduced generation of anti-nucleocapsid IgG and nAb compared to adults, has been associated with a milder disease course [63].

\section{Implications of waning antibodies on COVID-19}

\section{Underlying mechanisms of antibody waning}

In SARS-CoV-2 the initial rapid waning of antibodies is thought to be due to the loss of short-lived plasma cells, while the plateau in antibody levels occurs due to establishment of long-lived plasma cells [65]. The underlying causes of waning were investigated in a recent paper by Kaneko et al., which found the absence of germinal centres in the thoracic lymph nodes of deceased SARS-CoV-2 patients [66]. They proposed this lack of germinal centres was due to defective Bcl6+ follicular T-cells, which are unable to activate memory B-cells (MBCs). In turn this would impair the production of long-lasting and high-affinity antibodies, which could explain the rapid waning of antibodies in SARS-CoV-2 [66]. A similar mechanism for rapid waning of antibodies was proposed in SARS-CoV, where it was found that the virus depleted key lymphocytes involved in immune signalling and affected germinal centre responses [67]. However, since both studies were done on deceased patients, these mechanisms only explain waning in the most severe cases.

\section{Duration of antibody-mediated immunity}

Time to reinfection can help determine the duration of protective immunity. Unlike other coronaviruses, reinfections with HCoVs have been widely observed. These usually occur within 12 months of the preceding infection, though some manifest as early as 6 months with no association with waning antibodies $[52,53,68]$. It is important to note that reinfection with $\mathrm{HCoVs}$ may be associated with less severe disease and a shorter duration of shedding, but results have been contradicting [51, 52, 69].

Furthermore, a lack of genotypic difference between reinfecting HCoV-NL63 strains has been confirmed which means mutations may not be responsible for reinfections and therefore, antibody-mediated immunity to $\mathrm{HCoVs}$ is shortlasting if at all protective [70]. In two rhesus macaque trials, previous SARS-CoV-2 infection was protective against reinfection when re-exposed at 28 and 35 days, showing greater $\mathrm{nAb}$ titre production upon re-challenge in comparison to primary challenge [71, 72]. While SARS-CoV-2 reinfection 
cases are rare, they have occurred, with one study reporting a reinfection rate of $0.02 \%$ and median time to reinfection of 64.5 days [73]; this is shorter than what is seen with HCoVs, suggesting a relatively short period of protective immunity. However, this study may have overestimated the reinfection rate due to diagnostic error and a small sample size [73].

A correlation between severity of illness and magnitude of humoral response in MERS-CoV, SARS-CoV and SARSCoV-2 has been reported [7, 34-36, 43, 59]. In the case of SARS-CoV and MERS-CoV, this has been associated with a longer time to seronegativity, but results have been conflicting [20, 23, 26, 33, 34]. Therefore, whether severe cases of SARS-CoV-2 will have longer lasting immunity remains to be confirmed.

\section{Efficacy of antibodies}

The efficacy of antibodies is a crucial aspect of immunity. Some studies have suggested that antibodies are not sufficient for viral clearance [74]; this is supported by the absence of an abrupt decline in viral load after seroconversion [75]. One way of assessing the efficacy of antibodies may be through the observation of patient response to convalescent plasma transfer therapy (CPTT). Studies of CPTT in SARS-CoV-2 have shown varied results on the protective role of nAbs. Initially, CPTT demonstrated encouraging results in case-control studies for severe SARS-CoV-2 $[76,77]$, with some studies proposing earlier therapy being more beneficial $[77,78]$. Early CPTT was also found to be beneficial in SARS-CoV [79]. However, recently published data from large-scale randomised controlled trials did not identify any significant reduction in mortality or improvements in clinical outcomes for those with mild or severe SARS-CoV-2 receiving CPTT $[80,81]$. This suggests that the antibody response alone may not be as important as once thought in SARS-CoV-2 immunity.

In cases of recovered COVID-19, assessing the efficacy of antibodies against reinfection is difficult. For example, a large COVID-19 outbreak on a Seattle fishery vessel infecting over $85 \%$ of the crew on board showed that those who were positive for nAbs (titres ranging from 1:161 to 1:3082), prior to departure successfully remained infection-free [82]. However, this correlation of antibodies and protection does not necessarily imply a causative relationship.

Previous in vivo and in vitro studies with MERS-CoV and SARS-CoV have cautioned of antibody-dependent enhancement (ADE) in SARS-CoV-2 [83]. While ADE has not been noted in COVID-19 patients so far, preliminary findings from an in vitro analysis of COVID-19 convalescent plasma identified a significantly greater likelihood of ADE for patients who were older, had a more severe infection and a longer disease duration [84]. ADE was greatest in plasma with high titres of SARS-CoV-2-specific anti-RBD and anti-S 1 antibodies [84]. Importantly, cross-reactive antibodies from other coronaviruses were excluded as the cause of ADE [84]. While the mechanism of ADE here is not clear, it could suggest a less efficacious antibody response in certain cohorts.

\section{B- and T-cell immunity}

In $10-30 \%$ of recovered COVID-19 cases, antibody titres are low or undetectable $[85,86]$. Therefore, other aspects of humoral immunity are likely at play [87, 88]. For example, MBCs are thought to be maintained independently of antibody levels, which means B-cell immunity may persist even if antibodies wane [89]. Though, it has been noted that MBCs in SARS-CoV are undetectable 6 years after infection [33]. In SARS-CoV-2, MBCs (specific to spike and nucleocapsid proteins) and memory T-cells (MTCs) have been shown to persist for at least 3 months when antibody levels decline, but follow-up has been limited due to the ongoing pandemic [87, 88].

Promisingly, MTCs in MERS-CoV and SARS-CoV have been shown to persist for 10 years [90] and 17 years [91], respectively, which shows potential for long-lasting immunity against SARS-CoV-2. However, whether T-cells can form protective immunity without an antibody response is still uncertain and cannot be deduced from SARS-CoV, as this no longer circulates to cause reinfection [15, 92]. Furthermore, levels of $\operatorname{IgG}$ and $\operatorname{IgA}$ have been shown to correlate with the number of specific $\mathrm{CD} 4^{+} \mathrm{T}$-cells, therefore it may be that T-cells can wane in a similar manner to antibodies [93].

It is known that cellular immunity is important in protection against viral infection, given that children without it have worse outcomes than those with low or absent antibody titres in conditions such as hypogammaglobulinaemia or agammaglobulinaemia [94]. Additionally, a report of COVID-19 in two patients with agammaglobulinaemia showed recovery without severe disease suggesting T-cells may be more important in overcoming SARS-CoV-2 infection than B-cells [95]. The importance of T-cells has also been highlighted in studies showing worse COVID-19 outcomes in HIV patients not on antiretroviral therapy (ART) compared to those on ART; worse outcomes potentially being attributed to increased T-cell exhaustion in these patients [96, 97]. However, reports of reinfection or possible persistence of SARS-CoV-2 in patients on B-cell depleting immunosuppressants, e.g. rituximab, which prevent the generation of an antibody response to SARS-CoV-2, suggest that antibodies are likely to be vital in protection against reinfection [98, 99]. 


\section{Cross-reactivity and trained immunity}

In serological studies of SARS-CoV-2 it is widely assumed that the antibody response mounted is against a novel virus. However, HCoV cross-reactivity may be affecting the antibody dynamics [100] and it has been suggested to be the reason for lower disease severity in children and lower death rates in low- and middle-income countries [101, 102]. Nevertheless, in vitro, pre-existing cross-reactive antibodies were not protective against SARS-CoV-2 infection of Vero E6 cells [100].

Some have suggested a possible anamnestic response in SARS-CoV-2 from pre-existing MBCs. A study [103] identified that $>80 \%$ of low-affinity antibodies which crossreacted to SARS-CoV and SARS-CoV-2 also reacted to spike protein components of $\mathrm{HCoV}$. These cross-reactive antibodies had higher levels of clonal expansion than those which only reacted to SARS-CoV and SARS-CoV-2, possibly suggesting a boosted response from pre-existing MBCs [103]. This cross-reactivity may mean that initial immunity for SARS-CoV-2 is higher than expected, which could have positive implications for herd immunity [104]. Furthermore, when examining cross-reactivity, the observed results may be due to defective assays and more studies need to make the distinction between cross-reactivity and cross-binding [105].

A pre-existing $\mathrm{nAb}$ response has also been noted in MERS-CoV and SARS-CoV-2 vaccine clinical trials [106, 107], likely due to antibody cross-reactivity with HCoVs. However, in both groups this did not alter the vaccine immunogenicity profile or subsequent antibody dynamics, indicating SARS-CoV-2 vaccinations would not have reduced immunogenicity despite interactions with other seasonal coronaviruses. This has positive implications in the scenario where SARS-CoV-2 outbreaks become a yearly phenomenon.

Innate immunity can also be "trained" using vaccines such as Bacillus Calmette-Guérin (BCG) and microbial elements, e.g. lipopolysaccharides, inducing epigenetic and metabolic changes in myeloid cells [108]. BCG vaccinations have previously been shown to be protective through the enhancement of antibody release in influenza A (H1N1), reduction in clinical manifestations of herpes simplex virus infections and the decrease in yellow fever vaccine viraemia [109]. Recent epidemiological studies suggest that BCG vaccination may be protective against severe COVID-19 [110], though this may be affected by various confounding factors. Clinical trials to confirm potential benefits in response to SARS-CoV-2 are ongoing, e.g. NCT04659941, NCT04537663 and NCT04327206.

\section{Vaccines}

\section{Viral vector vaccines}

The relatively rapid resolution of SARS-CoV and MERS$\mathrm{CoV}$, and lack of interest in $\mathrm{HCoV}$ research has resulted in limited vaccination experience for coronaviruses [111]. However, the ChAdOx1 MERS trial has guided much of the current approach to the ChAdOx $1 \mathrm{nCoV}-19$ vaccine [106, 107]. Similarly to ChAdOx 1 MERS, ChAdOx 1 nCoV-19 produced a strong $\mathrm{IgG}$ and $\mathrm{nAb}$ response, with a peak in antibody titres by day 28 that remained elevated at day 56 [106, 107, 112]. In the ChAdOx1 MERS trial, waning of antibodies continued to day 182 , though levels plateaued after this point, remaining detectable even at the end of the 346-day follow-up period [106]. However, it is unclear if such low titres are protective against infection.

Furthermore, antibodies to the viral vector ChAdOx 1 have the potential to impact vaccine efficacy, hence the use of a simian virus with rare pre-existing immunity in the aforementioned trials [113, 114]. After prime vaccination in the ChAdOx1 nCoV-19 trial, anti-ChAdOx1 nAb increased in both low and standard dosages, peaking by day 28. Antibodies plateaued at this level even after the booster dose until the end of follow-up at day 56 [112]. Studies have noted that low levels of pre-existing nAb to simian adenovirus vectors do not reduce the vaccine-induced immunological response [114, 115]. However, higher levels of vector $\mathrm{nAb}$ triggered by prime vaccination may interfere with subsequent booster doses, as indicated in the phase II/III ChAdOx1 nCoV-19 trial which noted a weak inverse correlation between anti-ChAdOx1 nAb and anti-spike $\operatorname{IgG}$ [112]. This might explain the greater efficacy of the ChAdOx1 $\mathrm{nCoV}-19$ vaccine with greater interval between the priming and booster doses $[84,116]$.

In the case of Sputnik-V, the heterologous combination of the rAd26-S and rAd5-S adenovirus vectors mitigated the issue of primer-induced anti-vector antibodies and could be why a higher efficacy of $91.6 \%$ (95\% confidence interval, CI 85.6-95.2\%) was seen [117] compared to the $66.7 \%$ (95\% CI 57.4-74.0\%) of ChAdOx1 nCoV-19 [116] at preventing symptomatic COVID-19. Importantly, models have predicted that as variants arise which are less susceptible to pre-existing vaccine-induced $\mathrm{nAb}$, vaccines with higher initial efficacy against the wild-type would similarly provide higher efficacy against variants $[112,118]$.

\section{mRNA vaccines}

Despite their novelty, the BNT162b2 and mRNA-1273 mRNA vaccines have successfully demonstrated robust ability at generating $\mathrm{nAb}$ titres at levels superior to most other vaccines, including viral vector approaches [118]. 
Expectedly, the increased titre correlates with increased vaccine-mediated protection from COVID-19 of 95\% (95\% CI 90.3-97.6\%) and $94.1 \%$ (95\% CI 89.3-96.8\%) for the BNT162b2 and mRNA-1273 vaccines, respectively [118-120]. Similarly to ChAdOx1 nCoV-19, increased intervals between primer and booster mRNA vaccine doses have yielded superior $\mathrm{nAb}$ titres. However, a study by Parry et al. noted that this may come at the cost of a reduced cellular immune response [121]. Additionally, an age-related decrease in mRNA vaccine-induced antibodies and cellular responses were noted by several studies [122-126], with some reporting faster waning in older age groups [122]. Therefore, additional investigation on the impact of dosing schedules for different age groups is warranted. Waning of mRNA vaccine-induced nAb responses have also been reported as early as 6 weeks post-booster dose, continuing at 12 weeks [122], but longer follow-up is crucial.

\section{Natural infection and vaccination}

Vaccines generally induce comparable or greater antibody titres against SARS-CoV-2 than natural infection, which is differentiated from vaccine-acquired immunity by the presence of anti-nucleocapsid antibodies. Three weeks after a single dose of the BNT162b2 vaccine, comparable anti-spike IgG titres to convalescent patients are induced, rising significantly 1 week after the subsequent booster dose [122]. Similarly, nAb levels induced after complete regimens of NVX-CoV2373, mRNA-1273 and Sputnik-V have all shown higher $\mathrm{nAb}$ titres than convalescent samples [118]. Results of ChAdOx1 nCoV-19 trials have shown nAb titres near or below convalescent patients, corresponding to the lower protection offered than from some other vaccines [107, 118].

Single-dose vaccination of patients with previous SARS$\mathrm{CoV}-2$ exposure has been found to induce dramatic increases in titres of anti-spike IgG and nAbs [127], rivalling titres generated after booster doses in infection-naïve subjects $[128,129]$. Antibody responses after a single vaccine dose in those previously infected develop quicker and reach higher titres [123], a phenomenon occurring even when anti-spike IgG from previous SARS-CoV-2 infection had waned to low or undetectable levels [124], indicating immune memory despite waning of antibodies. This may be important in rationing vaccines [125], especially considering ongoing shortages around the world. However, despite the enhanced peak antibody response following vaccination post-infection, the subsequent 8 weeks of follow-up have shown a faster decline in antibody titres compared to infection-naïve vaccinated patients. Therefore, longer follow-up is needed to see if a higher plateau is finally reached [121].

\section{Vaccine mixing}

Studies into the immunogenicity of heterologous primeboost vaccination using the $\mathrm{ChAdOx} 1 \mathrm{nCoV}-19$ and BNT162b2 vaccines have been initiated. This combination of vaccines generated a stronger antibody response [126] than two doses of the ChAdOx1 nCoV-19 vaccine, likely as the neutralising effects of anti-vector nAbs were avoided, as with Sputnik-V [117, 130], although a comparison to two doses of the BNT162b2 vaccine is yet to be done.

Despite the positive antibody response with vaccine combinations, preliminary data suggest that mild-moderate side effects increase in frequency with mixed vaccines compared to two doses of the same vaccine [131]. All in all, further research is needed to determine the best vaccine regimen for long-term protection against SARS-CoV-2.

\section{Herd immunity and SARS-CoV-2 variants}

For SARS-CoV-2, it was initially estimated that at least $50-66.7 \%$ of the population needs to be immune [132] in order to achieve herd immunity. Assuming this level of immunity can be reached, the length of time and effectiveness of the immune response is an important consideration [132], as transient immunity from antibody waning would mean COVID-19 outbreaks could become biennial or annual [104]. Achieving this through natural infection is unlikely to be a viable option due to unacceptably high morbidity and mortality rates. This was evident in an uncontrolled outbreak of SARS-CoV-2 infection in the Amazon area of Manaus, which experienced a 4.5 -fold increase in excess deaths when three quarters of the population were infected [133]. Theoretically, this should have been enough for herd immunity ( $>67 \%$ ) but Manaus unexpectedly experienced a second resurgence in January 2021 [134], just months after the first peak in June 2020 despite high seropositivity. Although other epidemiological studies show that naturally acquired immunity should be as protective against reinfection as vaccination for at least 5 months [135], achieving herd immunity through vaccinations appears more desirable.

The percentage required for herd immunity may be an underestimation due to under-reporting of cases [132] and the potentially lower transmissibility [136] of infection in children. Moreover, mutations conferring greater transmissibility, such as N501Y (found in B.1.1.7 and B.1.351 variants), E484K (found in the B.1.351 variant), and L452R and E484Q (found in the B.1.617.2 variant), increase the basic reproduction number [137-139] which in turn increases the percentage needed to achieve herd immunity [132].

Based on early results from in vitro studies of recovered SARS-CoV-2 patients' CPTT and neutralising monoclonal antibodies, it appears these mutations may result in decreased effectiveness of pre-existing antibodies [140]. 
Despite this possibility, recently a study [141] published that the B.1.1.7 variant has no significant impact on vaccine-induced immunity. Comparing the B.1.617.2 variant to the B.1.1.7 variant, only a small decrease in vaccine effectiveness 2 weeks after the second dose was seen for both the BNT162b2 (93.4\% to 87.9\%) and ChAdOx $1 \mathrm{nCoV}-19$ (66.1\% to $59.8 \%$ ) vaccines [142]. However, a decrease in effectiveness of either vaccine against B.1.617.2 was significantly more pronounced after only a single dose [142], stressing the importance of vaccine regimen completion. In addition, although the neutralisation titres reduce by 6.4 -fold for the B.1.351 variant, the titres remain high with the ability to neutralise pseudoviruses [140].

Interestingly, mRNA vaccines induce disproportionately more anti-RBD antibodies compared to natural infection, which tend to target other portions of the spike protein [143]. Vaccine-induced antibodies also target a broader range of areas on the RBD, meaning those antibodies are better able to respond potently against new variants even when they carry mutations in the RBD [143]. Therefore, while the emergence of new SARS-CoV-2 variants remains a threat to herd immunity, current vaccines remain effective and provide superior protection to natural disease.

Vaccine hesitancy, however, is a major challenge to achieving herd immunity and modelling suggests that countries with lower vaccine uptake may experience eightfold greater deaths over a 2-year period [144]. Promisingly, a recent study by Milman et al. has found that high levels of vaccine uptake reduce transmission of SARS-CoV-2 even in the unvaccinated cohorts [145], which may curb the pandemic. Given the presence of unvaccinated individuals, varying levels of immunological protection from vaccination/natural infection, potentially lower efficacy of vaccines against new variants and reports of reinfection, low-level transmission is expected to continue after the end of the pandemic. However, severity of these infections is likely to be much lower even with low nAb titres [118]. Endemic circulation such as that of $\mathrm{HCoVs}$, which probably caused similar pandemics in the past, will likely maintain population immunity against SARS-CoV-2 [146]. This may eliminate the need for booster vaccinations.

\section{Limitations and future}

Given the low case fatality seen in HCoVs as well as the relatively small outbreaks of SARS-CoV and MERS-CoV, prior research into coronaviruses has been lacking. Additionally, the most genetically homologous coronavirus, SARS$\mathrm{CoV}$, no longer circulates [15] which puts limits on what we can deduce about the long-term efficacy of the immune response against it. Moreover, due to the fast-evolving nature and high volume of scientific publishing on COVID-19, this review may lack inclusion of more recent studies.

Studies have also noted that antibodies specific to certain viral antigen, such as nucleocapsid or spike protein may wane at different rates [147-149], though it is unclear to what extent this may be due to inaccuracies in the serological method employed. The limited research addressing antibody targets for SARS-CoV, MERS-CoV and HCoVs makes it difficult to contextualise their importance. Enzymelinked immunosorbent assay (ELISA) is one of the most frequently used assays in determining antibody-specific IgG titres though substantial variations exist in its sensitivity and specificity [150]. Furthermore, while the plaque reduction neutralisation test (PRNT) is considered the "gold standard" $[12,151]$ in assessing the functional ability of antibodies in viral neutralisation, other simpler assays have frequently been used. These generally correlate well to PRNT [12], though this heterogeneity of platforms remains an important caveat when comparing results.

A further limitation of the current body of research is the lack of focus on mucosal immunity and the waning of secretory IgA. Secretory IgA is known to have a crucially protective function at the mucosal surface [152] and is possibly an even more potent neutraliser of SARS-CoV-2 than IgG [153]. If further research into this proves fruitful, the mucosal route of vaccine delivery could be of greater interest.

Existing literature shows that antibodies to coronavirus infections wane over time but is difficult to quantify what antibody titre conveys protection from SARS-CoV-2 and for how long titres can be maintained above this threshold. To address these points, animal re-challenge studies of SARS$\mathrm{CoV}-2$ could be initiated with a longer time interval to reinfection, as only a short-time window of $\sim 30$ days has been tested [71, 72].

\section{Conclusion}

The last 20 years have taught us that coronaviruses have immense pandemic potential and should be monitored carefully. By reviewing the literature on SARS-CoV, MERS$\mathrm{CoV}$ and HCoVs, we have concluded that high antibody titres to SARS-CoV-2 are unlikely to be maintained in the long-term; antibodies to most coronaviruses wane to undetectable titres within 2 years of infection and within 6-12 months following $\mathrm{HCoV}$ infections. Furthermore, although various vaccine platforms have proven their ability to induce robust antibody responses, this is accompanied by subsequent waning, making reinfection a possibility unless "booster" doses are administered. Therefore, public health measures relying on the induction and monitoring of antibodies for herd immunity should be considered carefully. 
Nevertheless, there is evidence that B- and T-cells persist for longer than antibodies and vaccines targeting these may be a promising strategy for long-term immunity. However, these also require further research to determine their protective capacity.

Acknowledgements We would like to thank Professor Daniel Altmann for taking the time to critically read and comment on this manuscript.

Author contributions These authors contributed equally to this work. All authors were involved in the conceptualisation, literature search, data analysis, writing and editing of this manuscript.

Funding Not applicable.

Data availability All data published were publicly available.

Code availability Not applicable.

\section{Declarations}

Conflict of interest The authors declare that they have no conflict of interest.

Ethical approval This manuscript did not require prior ethical consent.

Informed consent Not applicable.

Consent for publication Not applicable.

Open Access This article is licensed under a Creative Commons Attribution 4.0 International License, which permits use, sharing, adaptation, distribution and reproduction in any medium or format, as long as you give appropriate credit to the original author(s) and the source, provide a link to the Creative Commons licence, and indicate if changes were made. The images or other third party material in this article are included in the article's Creative Commons licence, unless indicated otherwise in a credit line to the material. If material is not included in the article's Creative Commons licence and your intended use is not permitted by statutory regulation or exceeds the permitted use, you will need to obtain permission directly from the copyright holder. To view a copy of this licence, visit http://creativecommons.org/licenses/by/4.0/.

\section{References}

1. Dong E, Du H, Gardner L. An interactive web-based dashboard to track COVID-19 in real time. Lancet Infect Dis. 2020. https:// doi.org/10.1016/S1473-3099(20)30120-1.

2. World Health Organisation. Immunization, vaccines and biologicals - the immunological basis for immunization series. https:// www.who.int/immunization/documents/immunological_basis_ series/en/. Accessed 20 Jan 2021.

3. Klasse PJ. Neutralization of virus infectivity by antibodies: old problems in new perspectives. Adv Biol. 2014;2014: 157895. https://doi.org/10.1155/2014/157895.

4. Mulligan MJ, Lyke KE, Kitchin N, Absalon J, Gurtman A, Lockhart S, et al. Phase I/II study of COVID-19 RNA vaccine BNT162b1 in adults. Nature. 2020. https://doi.org/10.1038/ s41586-020-2639-4.
5. Long Q, Liu B, Deng H, Wu G, Deng K, Chen Y, et al. Antibody responses to SARS-CoV-2 in patients with COVID-19. Nat Med. 2020;26:845-8. https://doi.org/10.1038/s41591-020-0897-1.

6. Nag DS, Chaudhry R, Mishra M, Rai S, Gupta M. A prospective study on rapidly declining SARS-CoV-2 IgG antibodies within one to three months of testing IgG positive: can it lead to potential reinfections? Cureus. 2020;12: e11845. https://doi.org/10. 7759/cureus. 11845 .

7. Seow J, Graham C, Merrick B, Acors S, Pickering S, Steel KJA, et al. Longitudinal observation and decline of neutralizing antibody responses in the three months following SARS-CoV-2 infection in humans. Nat Microbiol. 2020;5:1598-607. https:// doi.org/10.1038/s41564-020-00813-8.

8. Su S, Wong G, Shi W, Liu J, Lai ACK, Zhou J, et al. Epidemiology, genetic recombination, and pathogenesis of coronaviruses. Trends Microbiol. 2016;24:490-502. https://doi.org/10.1016/j. tim.2016.03.003.

9. King A. An uncommon cold. N Sci. 2020;246:32-5. https://doi. org/10.1016/S0262-4079(20)30862-9.

10. McIntosh K, Perlman S. Coronaviruses, including severe acute respiratory syndrome (SARS) and Middle East respiratory syndrome (MERS). In: Mandell, Douglas, and Bennett's principles and practice of infectious diseases. Amsterdam: Elsevier; 2015. pp. 1928-36.e2. https://doi.org/10.1016/B978-1-4557-4801-3. 00157-0.

11. Corman VM, Muth D, Niemeyer D, Drosten C. Hosts and sources of endemic human coronaviruses. Adv Virus Res. 2018;100:16388. https://doi.org/10.1016/bs.aivir.2018.01.001.

12. Okba NMA, Müller MA, Li W, Wang C, Geurtsvankessel CH, Corman VM, et al. Severe acute respiratory syndrome coronavirus 2-specific antibody responses in coronavirus disease patients. Emerg Infect Dis. 2020;26:1478-88. https://doi.org/10.3201/ eid2607.200841.

13. Kaur N, Singh R, Dar Z, Bijarnia RK, Dhingra N, Kaur T. Genetic comparison among various coronavirus strains for the identification of potential vaccine targets of SARS-CoV2. Infect Genet Evol. 2020. https://doi.org/10.1016/j.meegid.2020.

14. World Health Organisation EMRO. MERS situation update, MERS-CoV epidemic and pandemic diseases. WHO; 2020. http://www.emro.who.int/pandemic-epidemic-diseases/merscov/mers-situation-update-january-2020.html. Accessed 20 Jan 2021.

15. World Health Organization. Severe acute respiratory syndrome (SARS). https://www.who.int/health-topics/severe-acute-respi ratory-syndrome\#tab=tab_1. Accessed 20 Jan 2021.

16. Chan KS, Zheng JP, Mok YW, LIi YM, Liu Y, Chu CM, et al. SARS: prognosis, outcome and sequelae. Respirology. 2003;8:S36-40. https://doi.org/10.1046/j.1440-1843.2003. 00522.x.

17. Saad M, Omrani AS, Baig K, Bahloul A, Elzein F, Matin MA, et al. Clinical aspects and outcomes of 70 patients with Middle East respiratory syndrome coronavirus infection: a single-center experience in Saudi Arabia. Int J Infect Dis. 2014;29:301-6. https://doi.org/10.1016/j.ijid.2014.09.003.

18. Ganesh B, Rajakumar T, Malathi M, Manikandan N, Nagaraj J, Santhakumar A, et al. Epidemiology and pathobiology of SARS-CoV-2 (COVID-19) in comparison with SARS, MERS: an updated overview of current knowledge and future perspectives. Clin Epidemiol Glob Health. 2021;10: 100694. https://doi. org/10.1016/j.cegh.2020.100694.

19. Conzade R, Grant R, Malik MR, Elkholy A, Elhakim M, Samhouri $\mathrm{D}$, et al. Reported direct and indirect contact with Dromedary camels among laboratory-confirmed MERS-CoV cases. Viruses. 2018;10:425. https://doi.org/10.3390/v10080425.

20. Xiao S, Li Y, Sung M, Wei J, Yang Z. A study of the probable transmission routes of MERS-CoV during the first hospital 
outbreak in the Republic of Korea. Indoor Air. 2018;28:51-63. https://doi.org/10.1111/ina.12430.

21. Abdul-Rasool S, Fielding BC. Understanding human coronavirus HCoV-NL63. Open Virol J. 2010;4:76-84. https://doi.org/ 10.2174/1874357901004010076.

22. Fischer N, Dauby N, Bossuyt N, Reynders M, Gérard M, Lacor $\mathrm{P}$, et al. Monitoring of human coronaviruses in Belgian primary care and hospitals, 2015-20: a surveillance study. Lancet Microbe. 2021;2:e105-14. https://doi.org/10.1016/S26665247(20)30221-4.

23. Booth A, Reed AB, Ponzo S, Yassaee A, Aral M, Plans D, et al. Population risk factors for severe disease and mortality in COVID-19: a global systematic review and meta-analysis. PLoS ONE. 2021;16: e0247461. https://doi.org/10.1371/journal.pone. 0247461.

24. Leung NHL. Transmissibility and transmission of respiratory viruses. Nat Rev Microbiol. 2021;22:1-18. https://doi.org/10. 1038/s41579-021-00535-6.

25. Zhao J, Cui W, Tian BP. The potential intermediate hosts for SARS-CoV-2. Front Microbiol. 2020;11: 580137. https://doi.org/ 10.3389/fmicb.2020.580137.

26. Tai W, He L, Zhang X, Pu J, Voronin D, Jiang S, et al. Characterization of the receptor-binding domain (RBD) of 2019 novel coronavirus: implication for development of RBD protein as a viral attachment inhibitor and vaccine. Cell Mol Immunol. 2020;17:613-20. https://doi.org/10.1038/s41423-020-0400-4.

27. Buchholz UJ, Bukreyev A, Yang L, Lamirande EW, Murphy BR, Subbarao K, et al. Contributions of the structural proteins of severe acute respiratory syndrome coronavirus to protective immunity. Proc Natl Acad Sci USA. 2004;101:9804-9. https:// doi.org/10.1073/pnas.0403492101.

28. Wu L, Wang N, Chang Y, Tian X, Na D, Zhang L, et al. Duration of antibody responses after severe acute respiratory syndrome. Emerg Infect Dis. 2007;13:1562-4. https://doi.org/10.3201/eid13 10.070576 .

29. Mo H, Zeng G, Ren X, Li H, Ke C, Tan Y, et al. Longitudinal profile of antibodies against SARS-coronavirus in SARS patients and their clinical significance. Respirology. 2006;11:49-53. https://doi.org/10.1111/j.1440-1843.2006.00783.x.

30. Yang Z, Wang S, Li Q, Li Y, Wei M, Gao H, et al. Determining SARS sub-clinical infection: a longitudinal seroepidemiological study in recovered SARS patients and controls after an outbreak in a general hospital. Scand J Infect Dis. 2009;41:507-10. https:// doi.org/10.1080/00365540902919384.

31. Liu W, Fontanet A, Zhang P, Zhan L, Xin Z, Baril L, et al. Two-year prospective study of the humoral immune response of patients with severe acute respiratory syndrome. J Infect Dis. 2006;193:792-5. https://doi.org/10.1086/500469.

32. Woo PCY, Lau SKP, Wong BHL, Chan K, Chu C, Tsoi H, et al. Longitudinal profile of immunoglobulin $\mathrm{G}(\mathrm{IgG}), \operatorname{IgM}$, and IgA antibodies against the severe acute respiratory syndrome (SARS) coronavirus nucleocapsid protein in patients with pneumonia due to the SARS coronavirus. Clin Diagn Lab Immunol. 2004;11:665-8. https://doi.org/10.1128/CDLI.11.4.665-668. 2004.

33. Tang F, Quan Y, Xin Z, Wrammert J, Ma M, Lv H, et al. Lack of peripheral memory $\mathrm{B}$ cell responses in recovered patients with severe acute respiratory syndrome: a six-year follow-up study. J Immunol. 2011;186:7264-8. https://doi.org/10.4049/jimmunol. 0903490.

34. Ho M, Chen W, Chen H, Lin S, Wang M, Di J, et al. Neutralizing antibody response and SARS severity. Emerg Infect Dis. 2005;11:1730-7. https://doi.org/10.3201/eid1111.040659.

35. Chang W, Kao C, Chung M, Chen S, Lin S, Chiang W, et al. SARS exposure and emergency department workers. Emerg
Infect Dis. 2004;10:1117-9. https://doi.org/10.3201/eid1006. 030972.

36. Wilder-Smith A, Teleman MD, Heng BH, Earnest A, Ling AE, Leo YS. Asymptomatic SARS coronavirus infection among healthcare workers, Singapore. Emerg Infect Dis. 2005;11:11425. https://doi.org/10.3201/eid1107.041165.

37. Hsueh P, Huang L, Chen P, Kao C, Yang P. Chronological evolution of IgM, IgA, IgG and neutralisation antibodies after infection with SARS-associated coronavirus. Clin Microbiol Infect. 2004;10:1062-6. https://doi.org/10.1111/j.1469-0691.2004. 01009.x.

38. Corman VM, Albarrak AM, Omrani AS, Albarrak MM, Farah ME, Almasri M, et al. Viral shedding and antibody response in 37 patients with Middle East respiratory syndrome coronavirus infection. Clin Infect Dis. 2016;62:477-83. https://doi.org/10. 1093/cid/civ951.

39. Spanakis N, Tsiodras S, Haagmans BL, Raj VS, Pontikis K, Koutsoukou A, et al. Virological and serological analysis of a recent Middle East respiratory syndrome coronavirus infection case on a triple combination antiviral regimen. Int J Antimicrob Agents. 2014;44:528-32. https://doi.org/10.1016/j.ijantimicag. 2014.07.026.

40. Park WB, Perera RAPM, Choe PG, Lau EHY, Choi SJ, Chun JY, et al. Kinetics of serologic responses to MERS coronavirus infection in humans, South Korea. Emerg Infect Dis. 2015;21:2186-9. https://doi.org/10.3201/eid2112.151421.

41. Huang AT, Garcia-Carreras B, Hitchings MDT, Yang B, Katzelnick LC, Rattigan SM, et al. A systematic review of antibody mediated immunity to coronaviruses: kinetics, correlates of protection, and association with severity. Nat Commun. 2020;11:4704. https://doi.org/10.1038/s41467-020-18450-4.

42. Ko J, Müller MA, Seok H, Park GE, Lee JY, Cho SY, et al. Serologic responses of 42 MERS-coronavirus-infected patients according to the disease severity. Diagn Microbiol Infect Dis. 2017;89:106-11. https://doi.org/10.1016/j.diagmicrobio.2017. 07.006 .

43. Alshukairi AN, Khalid I, Ahmed WA, Dada AM, Bayumi DT, Malic LS, et al. Antibody response and disease severity in healthcare worker MERS survivors. Emerg Infect Dis. 2016;22:11135. https://doi.org/10.3201/eid2206.160010.

44. Choe PG, Perera RAPM, Park WB, Song K, Bang JH, Kim ES, et al. MERS-CoV antibody responses 1 year after symptom onset, South Korea, 2015. Emerg Infect Dis. 2017;23:1079-84. https://doi.org/10.3201/eid2307.170310.

45. Payne DC, Iblan I, Rha B, Alqasrawi S, Haddadin A, Nsour MA, et al. Persistence of antibodies against Middle East respiratory syndrome coronavirus. Emerg Infect Dis. 2016;22:1824-6. https://doi.org/10.3201/eid2210.160706.

46. Zhao J, Alshukairi AN, Baharoon SA, Ahmed WA, Bokhari AA, Nehdi AM, et al. Recovery from the Middle East respiratory syndrome is associated with antibody and T cell responses. Sci Immunol. 2017;2:eaan5393. https://doi.org/10.1126/sciimmunol. aan5393.

47. Zhou W, Wang W, Wang H, Lu R, Tan W. First infection by all four non-severe acute respiratory syndrome human coronaviruses takes place during childhood. BMC Infect Dis. 2013;13:433. https://doi.org/10.1186/1471-2334-13-433.

48. Dijkman R, Jebbink MF, El Idrissi NB, Pyrc K, Müller MA, Kuijpers TW, et al. Human coronavirus NL63 and 229E seroconversion in children. J Clin Microbiol. 2008;46:2368-73. https:// doi.org/10.1128/JCM.00533-08.

49. Schmidt OW, Allan ID, Cooney MK, Foy HM, Fox JP. Rises in titers of antibody to human corona viruses OC43 and 229E in Seattle families during 1975-1979. Am J Epidemiol. 1986;123:862-8. https://doi.org/10.1093/oxfordjournals.aje. a114315. 
50. Ehrengut W, Sarateanu DE. A two year serological surveillance of coronavirus infections in Hamburg. Infection. 1980;8:70-2. https://doi.org/10.1007/BF01639150.

51. Galanti M, Shaman J. Direct observation of repeated infections with endemic coronaviruses. J Infect Dis. 2020;223:409-15. https://doi.org/10.1093/infdis/jiaa392.

52. Callow KA, Parry HF, Sergeant M, Tyrrell DA. The time course of the immune response to experimental coronavirus infection of man. Epidemiol Infect. 1990;105:435-46. https://doi.org/10. 1017/s0950268800048019.

53. Gaunt ER, Hardie A, Claas ECJ, Simmonds P, Templeton KE. Epidemiology and clinical presentations of the four human coronaviruses 229E, HKU1, NL63, and OC43 detected over 3 years using a novel multiplex real-time PCR method. J Clin Microbiol. 2010;48:2940-7. https://doi.org/10.1128/JCM.00636-10.

54. Darton TC, Blohmke CJ, Moorthy VS, Altmann DM, Hayden FG, Clutterbuck EA, et al. Design, recruitment, and microbiological considerations in human challenge studies. Lancet Infect Dis. 2015;15:840-51. https://doi.org/10.1016/S1473-3099(15) 00068-7.

55. Post N, Eddy D, Huntley C, van Schalkwyk MCI, Shrotri M, Leeman D, et al. Antibody response to SARS-CoV-2 infection in humans: a systematic review. PLoS ONE. 2020;15: e0244126. https://doi.org/10.1371/journal.pone.0244126.

56. Brochot E, Demey B, Touzé A, Belouzard S, Dubuisson J, Schmit $\mathrm{J}$, et al. Anti-spike, anti-nucleocapsid and neutralizing antibodies in SARS-CoV-2 inpatients and asymptomatic individuals. Front Microbiol. 2020;11:2468. https://doi.org/10.3389/fmicb.2020. 584251.

57. Ng DL, Goldgof GM, Shy BR, Levine AG, Balcerek J, Bapat SP, et al. SARS-CoV-2 seroprevalence and neutralizing activity in donor and patient blood. Nat Commun. 2020;11:4698. https:// doi.org/10.1038/s41467-020-18468-8.

58. Pelleau S, Woudenberg T, Rosado J, Donnadieu F, Garcia L, Obadia T, et al. Serological reconstruction of COVID-19 epidemics through analysis of antibody kinetics to SARS-CoV-2 proteins. medRxiv. 2021. https://doi.org/10.1101/2021.03.04. 21252532.

59. Lumley SF, Wei J, O’Donnell D, Stoesser NE, Matthews PC, Howarth A, et al. The duration, dynamics and determinants of SARS-CoV-2 antibody responses in individual healthcare workers. medRxiv. 2020. https://doi.org/10.1101/2020.11.02.20224 824.

60. Lau EHY, Tsang OTY, Hui DSC, Kwan MYW, Chan W, Chiu SS, et al. Neutralizing antibody titres in SARS-CoV-2 infections. Nat Commun. 2021;12:63. https://doi.org/10.1038/ s41467-020-20247-4.

61. Yang HS, Costa V, Racine-Brzostek SE, Acker KP, Yee J, Chen $\mathrm{Z}$, et al. Association of age with SARS-CoV-2 antibody response. JAMA Netw Open. 2021;4: e214302. https://doi.org/10.1001/ jamanetworkopen.2021.4302.

62. Liang ED, Epsi NJ, Richard SA, Samuels EC, Wang W, Vassell $\mathrm{R}$, et al. SARS-CoV-2 antibodies remain detectable 12 months after infection and antibody magnitude is associated with age and COVID-19 severity. medRxiv. 2021. https://doi.org/10.1101/ 2021.04.27.21256207.

63. Weisberg SP, Connors TJ, Zhu Y, Baldwin MR, Lin W, Wontakal $\mathrm{S}$, et al. Distinct antibody responses to SARS-CoV-2 in children and adults across the COVID-19 clinical spectrum. Nat Immunol. 2021;22:25-31. https://doi.org/10.1038/s41590-020-00826-9.

64. Sariol A, Perlman S. Lessons for COVID-19 immunity from other coronavirus infections. Immunity. 2020;53:248-63. https:// doi.org/10.1016/j.immuni.2020.07.005.

65. Selhorst P, Van Ierssel S, Michiels J, Mariën J, Bartholomeeusen K, Dirinck E, et al. Symptomatic SARS-CoV-2 reinfection of a health care worker in a Belgian nosocomial outbreak despite primary neutralizing antibody response. Clin Infect Dis. 2020. https://doi.org/10.1093/cid/ciaa1850.

66. Kaneko N, Kuo H, Boucau J, Farmer JR, Allard-Chamard H, Mahajan VS, et al. Loss of Bcl-6-expressing T follicular helper cells and germinal centers in COVID-19. Cell. 2020;183:143157.e13. https://doi.org/10.1016/j.cell.2020.08.025.

67. Gu J, Gong E, Zhang B, Zheng J, Gao Z, Zhong Y, et al. Multiple organ infection and the pathogenesis of SARS. J Exp Med. 2005;202:415-24. https://doi.org/10.1084/jem.20050828.

68. Eidge AWD, Kaczorowska J, Hoste ACR, Bakker M, Klein M, Loens K, et al. Seasonal coronavirus protective immunity is short-lasting. Nat Med. 2020;26:1691-3. https://doi.org/10. 1038/s41591-020-1083-1.

69. Kaye HS, Dowdle WR. Seroepidemiologic survey of coronavirus (strain 229E) infections in a population of children. Am J Epidemiol. 1975;101:238-44. https://doi.org/10.1093/oxfordjournals. aje.a112091.

70. Kiyuka PK, Agoti CN, Munywoki PK, Njeru R, Bett A, Otieno JR, et al. Human coronavirus NL63 molecular epidemiology and evolutionary patterns in rural coastal Kenya. J Infect Dis. 2018;217:1728-39. https://doi.org/10.1093/infdis/jiy098.

71. Deng W, Bao L, Liu J, Xiao C, Liu J, Xue J, et al. Primary exposure to SARS-CoV-2 protects against reinfection in rhesus macaques. Science. 2020;369:818-23. https://doi.org/10.1126/ science.abc5343.

72. Chandrashekar A, Liu J, Martinot AJ, McMahan K, Mercado NB, Peter L, et al. SARS-CoV-2 infection protects against rechallenge in Rhesus macaques. Science. 2020;369:812-7. https://doi.org/ 10.1126/science.abc4776.

73. Abu-Raddad LJ, Chemaitelly H, Malek JA, Ahmed AA, Mohamoud YA, Younuskunju S, et al. Assessment of the risk of SARS-CoV-2 reinfection in an intense re-exposure setting. Clin Infect Dis. 2020. https://doi.org/10.1093/cid/ciaa1846.

74. Zhao J, Yuan Q, Wang H, Liu W, Liao X, Su Y, et al. Antibody responses to SARS-CoV-2 in patients with novel coronavirus disease 2019. Clin Infect Dis. 2020;71:2027-34. https://doi. org/10.1093/cid/ciaa344.

75. Wölfel R, Corman VM, Guggemos W, Seilmaier M, Zange S, Müller MA, et al. Virological assessment of hospitalized patients with COVID-2019. Nature. 2020;581:465-9. https:// doi.org/10.1038/s41586-020-2196-X.

76. Shen C, Wang Z, Zhao F, Yang Y, Li J, Yuan J, et al. Treatment of 5 critically ill patients with COVID-19 with convalescent plasma. JAMA. 2020;323:1582-9. https://doi.org/10.1001/ jama.2020.4783.

77. Duan K, Liu B, Li C, Zhang H, Yu T, Qu J, et al. Effectiveness of convalescent plasma therapy in severe COVID-19 patients. Proc Natl Acad Sci USA. 2020;117:9490-6. https://doi.org/10. 1073/pnas.2004168117.

78. Salazar E, Christensen PA, Graviss EA, Nguyen DT, Castillo B, Chen J, et al. Significantly decreased mortality in a large cohort of coronavirus disease 2019 (COVID-19) patients transfused early with convalescent plasma containing high-titer anti-severe acute respiratory syndrome coronavirus 2 (SARSCoV-2) spike protein IgG. Am J Pathol. 2021;191:90-107. https://doi.org/10.1016/j.ajpath.2020.10.008.

79. Cheng Y, Wong R, Soo YOY, Wong WS, Lee CK, Ng MHL, et al. Use of convalescent plasma therapy in SARS patients in Hong Kong. Eur J Clin Microbiol Infect Dis. 2005;24:44-6. https://doi.org/10.1007/s10096-004-1271-9.

80. Simonovich VA, Burgos Pratx LD, Scibona P, Beruto MV, Vallone MG, Vázquez $\mathrm{C}$, et al. A randomized trial of convalescent plasma in COVID-19 severe pneumonia. N Engl J Med. 2020;384:619-29. https://doi.org/10.1056/NEJMoa2031304.

81. Agarwal A, Mukherjee A, Kumar G, Chatterjee P, Bhatnagar T, Malhotra P. Convalescent plasma in the management 
of moderate COVID-19 in adults in India: open label phase II multicentre randomised controlled trial (PLACID Trial). BMJ. 2020;371: m3939. https://doi.org/10.1136/bmj.m3939.

82. Addetia A, Crawford KHD, Dingens A, Zhu H, Roychoudhury P, Huang M, et al. Neutralizing antibodies correlate with protection from SARS-CoV-2 in humans during a fishery vessel outbreak with a high attack rate. J Clin Microbiol. 2020. https://doi.org/10.1128/JCM.02107-20.

83. Lee WS, Wheatley AK, Kent SJ, DeKosky BJ. Antibodydependent enhancement and SARS-CoV-2 vaccines and therapies. Nat Microbiol. 2020;5:1185-91. https://doi.org/10.1038/ s41564-020-00789-5.

84. Wu F, Yan R, Liu M, Liu Z, Wang Y, Luan D, et al. Antibodydependent enhancement (ADE) of SARS-CoV-2 infection 2 in recovered COVID-19 patients: studies based on cellular and structural biology analysis. medRxiv. 2020. https://doi.org/10. 1101/2020.10.08.20209114v1.

85. Tan W, Lu Y, Zhang J, Wang J, Dan Y, Tan Z, et al. Viral kinetics and antibody responses in patients with COVID-19. medRxiv. 2020. https://doi.org/10.1101/2020.03.24.20042382.

86. Wu F, Wang A, Liu M, Wang Q, Chen J, Xia S, et al. Neutralizing antibody responses to SARS-CoV-2 in a COVID-19 recovered patient cohort and their implications. medRxiv. 2020. https://doi.org/10.1101/2020.03.30.20047365.

87. Rodda LB, Netland J, Shehata L, Pruner KB, Morawski PA, Thouvenel CD, et al. Functional SARS-CoV-2-specific immune memory persists after mild COVID-19. Cell. 2021;184:169183.e17. https://doi.org/10.1016/j.cell.2020.11.029.

88. Hartley GE, Edwards ESJ, Aui PM, Varese N, Stojanovic S, McMahon J, et al. Rapid generation of durable B cell memory to SARS-CoV-2 spike and nucleocapsid proteins in COVID-19 and convalescence. Sci Immunol. 2020;5:eabf8891. https://doi. org/10.1126/sciimmunol.abf8891.

89. Amanna IJ, Carlson NE, Slifka MK. Duration of humoral immunity to common viral and vaccine antigens. N Engl J Med. 2007;357:1903-15. https://doi.org/10.1056/NEJMoa0660 92.

90. Rokni M, Ghasemi V, Tavakoli Z. Immune responses and pathogenesis of SARS-CoV-2 during an outbreak in Iran: comparison with SARS and MERS. Rev Med Virol. 2020;30: e2107. https:// doi.org/10.1002/rmv.2107.

91. Okoh AK, Bishburg E, Grinberg S, Nagarakanti S. Tocilizumab use in COVID-19-associated pneumonia. J Med Virol. 2021;93:1023-8. https://doi.org/10.1002/jmv.26471.

92. Sekine T, Perez-Potti A, Rivera-Ballesteros O, Strålin K, Gorin J, Olsson A, et al. Robust T cell immunity in convalescent individuals with asymptomatic or mild COVID-19. Cell. 2020;183:158168.e14. https://doi.org/10.1016/j.cell.2020.08.017.

93. Grifoni A, Weiskopf D, Ramirez SI, Mateus J, Dan JM, Moderbacher CR, et al. Targets of T cell responses to SARS-CoV-2 coronavirus in humans with COVID-19 disease and unexposed individuals. Cell. 2020;181:1489-1501.e15. https://doi.org/10. 1016/j.cell.2020.05.015.

94. Dörner T, Radbruch A. Antibodies and B cell memory in viral immunity. Immunity. 2007;27:384-92. https://doi.org/10.1016/j. immuni.2007.09.002.

95. Soresina A, Moratto D, Chiarini M, Paolillo C, Baresi G, Focà E, et al. Two X-linked agammaglobulinemia patients develop pneumonia as COVID-19 manifestation but recover. Pediatr Allergy Immunol. 2020;31:565-9. https://doi.org/10.1111/pai.13263.

96. Sharov KS. HIV/SARS-CoV-2 co-infection: T cell profile, cytokine dynamics and role of exhausted lymphocytes. Int $\mathbf{J}$ Infect Dis. 2021;102:163-9. https://doi.org/10.1016/j.ijid.2020. 10.049 .

97. Hoffmann C, Casado JL, Härter G, Vizcarra P, Moreno A, Cattaneo D, et al. Immune deficiency is a risk factor for severe
COVID-19 in people living with HIV. HIV Med. 2021;22:372-8. https://doi.org/10.1111/hiv.13037.

98. Gulati K, Prendecki M, Clarke C, Willicombe M, McAdoo S. COVID-19 reinfection in a patient receiving immunosuppressive treatment for antineutrophil cytoplasmic antibody-associated vasculitis. Arthritis Rheumatol. 2021;73:1091-2. https://doi.org/ 10.1002/art.41671.

99. Hunsinger DHP, Kutti Sridharan DG, Rokkam VRP, Fantry DLE. COVID-19 reinfection in an immunosuppressed patient without an antibody response. Am J Med Sci. 2021. https://doi.org/10. 1016/j.amjms.2021.02.003.

100. Ng KW, Faulkner N, Cornish GH, Rosa A, Harvey R, Hussain S, et al. Preexisting and de novo humoral immunity to SARS-CoV-2 in humans. Science. 2020;370:1339-43. https://doi.org/10.1126/ science.abe 1107.

101. Monto AS, DeJonge P, Callear AP, Bazzi LA, Capriola S, Malosh $\mathrm{RE}$, et al. Coronavirus occurrence and transmission over 8 years in the HIVE cohort of households in Michigan. J Infect Dis. 2020;222:9-16. https://doi.org/10.1093/infdis/jiaa161.

102. Capoor MN, Ahmed FS, McDowell A, Slaby O. Is the "Common Cold" our greatest ally in the battle against SARS-CoV-2? Front Cell Infect Microbiol. 2020;10: 605334. https://doi.org/10.3389/ fcimb.2020.605334.

103. Nguyen-Contant P, Embong AK, Kanagaiah P, Chaves FA, Yang $\mathrm{H}$, Branche AR, et al. S Protein-reactive IgG and memory B cell production after human SARS-CoV-2 infection includes broad reactivity to the $\mathrm{S} 2$ subunit. mBio. 2020. https://doi.org/10.1128/ mBio.01991-20.

104. Kissler SM, Tedijanto C, Goldstein E, Grad YH, Lipsitch M. Projecting the transmission dynamics of SARS-CoV-2 through the postpandemic period. Science. 2020;368:860-8. https://doi. org/10.1126/science.abb5793.

105. Lassaunière R, Frische A, Harboe ZB, Nielsen ACY, Fomsgaard A, Krogfelt KA, et al. Evaluation of nine commercial SARSCoV-2 immunoassays. medRxiv. 2020. https://doi.org/10.1101/ 2020.04.09.20056325.

106. Folegatti PM, Bittaye M, Flaxman A, Lopez FR, Bellamy D, Kupke A, et al. Safety and immunogenicity of a candidate Middle East respiratory syndrome coronavirus viral-vectored vaccine: a dose-escalation, open-label, non-randomised, uncontrolled, phase 1 trial. Lancet Infect Dis. 2020;20:816-26. https://doi. org/10.1016/S1473-3099(20)30160-2.

107. Folegatti PM, Ewer KJ, Aley PK, Angus B, Becker S, Belij-Rammerstorfer $\mathrm{S}$, et al. Safety and immunogenicity of the ChAdOx 1 nCoV-19 vaccine against SARS-CoV-2: a preliminary report of a phase $1 / 2$, single-blind, randomised controlled trial. Lancet. 2020;396:467-78. https://doi.org/10.1016/S0140-6736(20) 31604-4.

108. Netea MG, Domínguez-Andrés J, Barreiro LB, Chavakis T, Divangahi M, Fuchs E, et al. Defining trained immunity and its role in health and disease. Nat Rev Immunol. 2020;20:375-88. https://doi.org/10.1038/s41577-020-0285-6.

109. Arts R, Moorlag S, Novakovic B, Stunnenberg HG, van Crevel R, Netea MG. BCG vaccination protects against experimental viral infection in humans through the induction of cytokines associated with trained immunity. Cell Host Microbe. 2018;23:89-100. e5. https://doi.org/10.1016/j.chom.2017.12.010.

110. Escobar LE, Molina-Cruz A, Barillas-Mury C. BCG vaccine protection from severe coronavirus disease 2019 (COVID-19). Proc Natl Acad Sci USA. 2020;117:17720-6. https://doi.org/10. 1073/pnas.2008410117.

111. Li Y, Chi W, Su J, Ferrall L, Hung C, Wu TC. Coronavirus vaccine development: from SARS and MERS to COVID19. J Biomed Sci. 2020;27:104. https://doi.org/10.1186/ s12929-020-00695-2. 
112. Ramasamy MN, Minassian AM, Ewer KJ, Flaxman AL, Folegatti PM, Owens DR, et al. Safety and immunogenicity of ChAdOx1 nCoV-19 vaccine administered in a prime-boost regimen in young and old adults (COV002): a single-blind, randomised, controlled, phase 2/3 trial. Lancet. 2021;396:1979-93. https:// doi.org/10.1016/S0140-6736(20)32466-1.

113. Dicks MDJ, Spencer AJ, Edwards NJ, Wadell G, Bojang K, Gilbert SC, et al. A novel chimpanzee adenovirus vector with low human seroprevalence: improved systems for vector derivation and comparative immunogenicity. PLoS ONE. 2012;7: e40385. https://doi.org/10.1371/journal.pone.0040385.

114. O’Hara GA, Duncan CJA, Ewer KJ, Collins KA, Elias SC, Halstead FD, et al. Clinical assessment of a recombinant Simian adenovirus ChAd63: a potent new vaccine vector. J Infect Dis. 2012;205:772-81. https://doi.org/10.1093/infdis/jir850.

115. Ewer KJ, O'Hara GA, Duncan CJA, Collins KA, Sheehy SH, Reyes-Sandoval A, et al. Protective $\mathrm{CD}^{+}{ }^{+}$-cell immunity to human malaria induced by chimpanzee adenovirus-MVA immunisation. Nat Commun. 2013;4:2836. https://doi.org/10.1038/ ncomms3836.

116. Voysey M, Costa Clemens SA, Madhi SA, Weckx LY, Folegatti PM, Aley PK, et al. Single-dose administration and the influence of the timing of the booster dose on immunogenicity and efficacy of ChAdOx1 nCoV-19 (AZD1222) vaccine: a pooled analysis of four randomised trials. Lancet. 2021;397:881-91. https://doi.org/ 10.1016/S0140-6736(21)00432-3.

117. Logunov DY, Dolzhikova IV, Shcheblyakov DV, Tukhvatulin AI, Zubkova OV, Dzharullaeva AS, et al. Safety and efficacy of an rAd26 and rAd5 vector-based heterologous prime-boost COVID19 vaccine: an interim analysis of a randomised controlled phase 3 trial in Russia. Lancet. 2021;397:671-81. https://doi.org/10. 1016/S0140-6736(21)00234-8.

118. Khoury DS, Cromer D, Reynaldi A, Schlub TE, Wheatley AK, Juno JA, et al. Neutralizing antibody levels are highly predictive of immune protection from symptomatic SARS-CoV-2 infection. Nat Med. 2021. https://doi.org/10.1038/s41591-021-01377-8.

119. Skowronski DM, De Serres G, Vergnes J, Wang X, Absalon J, Koury K, et al. Safety and efficacy of the BNT162b2 mRNA COVID-19 vaccine. N Engl J Med. 2021;384:1576-8. https:// doi.org/10.1056/NEJMc2036242.

120. Baden LR, El Sahly HM, Essink B, Kotloff K, Frey S, Novak R, et al. Efficacy and safety of the mRNA-1273 SARS-CoV-2 vaccine. N Engl J Med. 2021;384:403-16. https://doi.org/10.1056/ NEJMoa2035389.

121. Parry H, Bruton R, Stephens C, Brown K, Amirthalingam $\mathrm{G}$, Hallis B, et al. Extended interval BNT162b2 vaccination enhances peak antibody generation in older people. medRxiv. 2021. https://doi.org/10.1101/2021.05.15.21257017.

122. Naaber P, Tserel L, Kangro K, Sepp E, Jürjenson V, Adamson A. Declined antibody responses to COVID-19 mRNA vaccine within first three months. medRxiv. 2021. https://doi.org/10. 1101/2021.04.19.21255714.

123. Saadat S, Rikhtegaran Tehrani Z, Logue J, Newman M, Frieman $\mathrm{MB}$, Harris $\mathrm{AD}$, et al. Binding and neutralization antibody titers after a single vaccine dose in health care workers previously infected with SARS-CoV-2. JAMA. 2021;325:1467-9. https:// doi.org/10.1001/jama.2021.3341.

124. Zipeto D, Carbonare LD, Valenti MT, Bisoffi Z, Piubelli C, Pizzato $\mathrm{M}$, et al. Antibody response to BTN162b2 mRNA vaccination in naïve versus SARS-CoV-2 infected subjects with and without waning immunity. Res Sq. 2021. https://doi.org/10. 21203/rs.3.rs-440410/v1.

125. Chahla RE, Tomas-Grau RH, Cazorla SI, Ploper D, Pingitore EV, López MA, et al. Past SARS-CoV-2 infection elicits a strong immune response after a single vaccine dose. medRxiv. 2021. https://doi.org/10.1101/2021.03.14.21253039.
126. Borobia AM, Carcas AJ, Olmeda M, Castaño L, Bertrán MJ, Pérez JG, et al. Reactogenicity and immunogenicity of BNT162b2 in subjects having received a first dose of ChAdOx1S: initial results of a randomised, adaptive, phase 2 trial (CombiVacS). SSRN. 2021. https://doi.org/10.2139/ssrn. 3854768.

127. Vickers MA, Sariol A, Leon J, Ehlers A, Locher AV, Dubay KA, et al. Exponential increase in neutralizing and spike specific antibodies following vaccination of COVID-19 convalescent plasma donors. Transfusion. 2021. https://doi.org/10.1111/trf.16401.

128. Gobbi F, Buonfrate D, Moro L, Rodari P, Piubelli C, Caldrer S, et al. Antibody response to the BNT162b2 mRNA COVID-19 vaccine in subjects with prior SARS-CoV-2 infection. Viruses. 2021;13:422. https://doi.org/10.3390/v13030422.

129. Ebinger JE, Fert-Bober J, Printsev I, Wu M, Sun N, Prostko JC, et al. Antibody responses to the BNT162b2 mRNA vaccine in individuals previously infected with SARS-CoV-2. Nat Med. 2021;27:981-4. https://doi.org/10.1038/s41591-021-01325-6.

130. Callaway E. Mix-and-match COVID vaccines trigger potent immune response. Nat News. 2021;593:491. https://www.nature. com/articles/d41586-021-01359-3. Accessed 11 June 2021.

131. Shaw RH, Stuart A, Greenland M, Liu X, Van-Tam JSN, Snape MD. Heterologous prime-boost COVID-19 vaccination: initial reactogenicity data. Lancet. 2021;397:2043-6. https://doi.org/ 10.1016/S0140-6736(21)01115-6.

132. Anderson RM, Vegvari C, Truscott J, Collyer BS. Challenges in creating herd immunity to SARS-CoV-2 infection by mass vaccination. Lancet. 2020;396:1614-6. https://doi.org/10.1016/ S0140-6736(20)32318-7.

133. Buss LF, Prete J, Carlos A, Abrahim CMM, Mendrone J, Alfredo ST, de Almeida-Neto $\mathrm{C}$, et al. Three-quarters attack rate of SARS-CoV-2 in the Brazilian Amazon during a largely unmitigated epidemic. Science (Am Assoc Adv Sci). 2021;371:288-92. https://doi.org/10.1126/science.abe9728.

134. Sabino EC, Buss LF, Carvalho MPS, Prete CA, Crispim MAE, Fraiji NA, et al. Resurgence of COVID-19 in Manaus, Brazil, despite high seroprevalence. Lancet. 2021;397:452-5. https:// doi.org/10.1016/S0140-6736(21)00183-5.

135. Shrestha NK, Burke PC, Nowacki AS, Terpeluk P, Gordon SM. Necessity of COVID-19 vaccination in previously infected individuals. medRxiv. 2021. https://doi.org/10.1101/2021.06.01. 21258176.

136. Goldstein E, Lipsitch M, Cevik M. On the effect of age on the transmission of SARS-CoV-2 in households, schools and the community. medRxiv. 2020. https://doi.org/10.1101/2020.07. 19.20157362 .

137. Leung K, Shum MH, Leung GM, Lam TT, Wu JT. Early transmissibility assessment of the N501Y mutant strains of SARSCoV-2 in the United Kingdom, October to November 2020. Eurosurveillance. 2021. https://doi.org/10.2807/1560-7917.ES. 2020.26.1.2002106.

138. Zahradník J, Marciano S, Shemesh M, Zoler E, Chiaravalli J, Meyer B, et al. SARS-CoV-2 RBD in vitro evolution follows contagious mutation spread, yet generates an able infection inhibitor. bioRxiv. 2021. https://doi.org/10.1101/2021.01.06.425392.

139. Hoffmann M, Hofmann-Winkler H, Krüger N, Kempf A, Nehlmeier I, Graichen L, et al. SARS-CoV-2 variant B.1.617 is resistant to Bamlanivimab and evades antibodies induced by infection and vaccination. bioRxiv. 2021. https://doi.org/10.1101/ 2021.05.04.442663.

140. European Center for Disease Prevention Control. Threat Assessment Brief: rapid increase of a SARS-CoV-2 variant with multiple spike protein mutations observed in the United Kingdom-20 December 2020. ECDC; 2020. https://www.ecdc.europa.eu/en/ publications-data/threat-assessment-brief-rapid-increase-sarscov-2-variant-united-kingdom. Accessed 16 Jan 2021. 
141. Wu K, Werner AP, Moliva JI, Koch M, Choi A, Stewart-Jones GB, et al. mRNA-1273 vaccine induces neutralizing antibodies against spike mutants from global SARS-CoV-2 variants. bioRxiv. 2021. https://doi.org/10.1101/2021.01.25.427948.

142. Bernal JL, Andrews N, Gower C, Gallagher E, Simmons R, Thelwall S, et al. Effectiveness of COVID-19 vaccines against the B.1.617.2 variant. medRxiv. 2021. https://doi.org/10.1101/2021. 05.22.21257658.

143. Greaney AJ, Loes AN, Gentles LE, Crawford K, Starr TN, Malone KD, et al. Antibodies elicited by mRNA-1273 vaccination bind more broadly to the receptor binding domain than do those from SARS-CoV-2 infection. Sci Transl Med. 2021. https:// doi.org/10.1126/scitranslmed.abi9915.

144. Mesa DO, Hogan AB, Watson OJ, Charles GD, Hauck K, Ghani $\mathrm{AC}$, et al. Report 43: quantifying the impact of vaccine hesitancy in prolonging the need for Non-Pharmaceutical Interventions to control the COVID-19 pandemic. London: Imperial College; 2021. https://www.imperial.ac.uk/mrc-global-infectious-disea se-analysis/covid-19/report-43-vaccine-hesitancy/. Accessed 20 June 2021.

145. Milman O, Yelin I, Aharony N, Katz R, Herzel E, Ben-Tov A, et al. Community-level evidence for SARS-CoV-2 vaccine protection of unvaccinated individuals. Nat Med. 2021. https://doi. org/10.1038/s41591-021-01407-5.

146. Veldhoen M, Simas JP. Endemic SARS-CoV-2 will maintain post-pandemic immunity. Nat Rev Immunol. 2021;21:131-2. https://doi.org/10.1038/s41577-020-00493-9.

147. Murrell I, Forde D, Tyson L, Chichester L, Garratt A, Vineall $\mathrm{O}$, et al. A longitudinal comparison of spike and nucleocapsid
SARS-CoV-2 antibody responses in a tertiary hospital's laboratory workers with validation of DBS specimen analysis. medRxiv. 2020. https://doi.org/10.1101/2020.10.29.20219931.

148. Bruni M, Cecatiello V, Diaz-Basabe A, Lattanzi G, Mileti E, Monzani S, et al. Persistence of anti-SARS-CoV-2 antibodies in non-hospitalized COVID-19 convalescent health care workers. J Clin Med. 2020. https://doi.org/10.3390/jcm9103188.

149. Grandjean L, Saso A, Ortiz AT, Lam T, Hatcher J, Thistlethwayte $\mathrm{R}$, et al. Long-term persistence of spike antibody and predictive modeling of antibody dynamics following infection with SARSCoV-2. medRxiv. 2020. https://doi.org/10.1101/2020.11.20. 20235697.

150. Lisboa Bastos M, Tavaziva G, Abidi SK, Campbell JR, Haraoui L, Johnston JC, et al. Diagnostic accuracy of serological tests for COVID-19: systematic review and meta-analysis. BMJ. 2020;370: m2516. https://doi.org/10.1136/bmj.m2516.

151. Perera RA, Mok CK, Tsang OT, Lv H, Ko RL, Wu NC, et al. Serological assays for severe acute respiratory syndrome coronavirus 2 (SARS-CoV-2), March 2020. Eurosurveillance. 2020. https://doi.org/10.2807/1560-7917.ES.2020.25.16.2000421.

152. Chen K, Magri G, Grasset EK, Cerutti A. Rethinking mucosal antibody responses: $\operatorname{IgM}, \operatorname{IgG}$ and $\operatorname{IgD}$ join $\operatorname{IgA}$. Nat Rev Immunol. 2020;20:427-41. https://doi.org/10.1038/ s41577-019-0261-1.

153. Wang Z, Lorenzi JCC, Muecksch F, Finkin S, Viant C, Gaebler $\mathrm{C}$, et al. Enhanced SARS-CoV-2 neutralization by dimeric IgA. Sci Transl Med. 2020;13(577):eabf1555. https://doi.org/10.1126/ scitranslmed.abf 1555 . 